\title{
RESPON BERBAGAI GENOTIPE JAGUNG UMUR GENJAH PADA BERBAGAI JARAK TANAM
}

\author{
(Response of Various Genotypes of Early Maturity at Various Plant Spacing) \\ St. Subaedah ${ }^{1}$, Sudirman Numba $^{1}$, Saida $^{1}$, A. Ralle $^{1}$ \\ ${ }^{1}$ Universitas Muslim Indonesia, Fakulty of Agriculture, Makassar, South Sulawesi, Indonesia \\ e-mail: st.subaedah@umi.ac.id \\ e-mail: numbasudirman@yahoo.com \\ e-mail: saidawahid@yahoo.co.id
}

\begin{abstract}
This study aims to analyze the response of various genotypes of early maturity at various plant spacing. The study was conducted from May to July 2017.The study was designed following a split-plot design pattern.As the main plot is the genotype of maize consisting of four genotypes G1, G2, G3, and G4.As a subplot is a spacing arrangement consisting of three levelnamely: sapacing of $70 \mathrm{~cm} \times 20 \mathrm{~cm}$ (J1), spacing of $60 \mathrm{~cm} \times 20 \mathrm{~cm}(\mathrm{~J} 2)$ and spacing of $50 \mathrm{~cm} \times 20 \mathrm{~cm}(\mathrm{~J} 3)$. The results showed that the growth and production of maize was affected by the genotype and spacing used. The maize genotypes G3 and G4 resulted in higher plants with a closer spacing $(60 \times 20 \mathrm{~cm}$ and $50 \times 20 \mathrm{~cm})$ than with wider plant spacing $(70 \times 20 \mathrm{~cm})$. In planting distance treatment showed that plant spacing of $60 \times 20 \mathrm{~cm}$ and $50 \times 20$ obtained significantly higher production that is between 8.95 to $9.35 \mathrm{t} /$ ha compared with the spacing of $70 \times 20 \mathrm{~cm}$ which produces only $7.64 \mathrm{t} / \mathrm{Ha}$.
\end{abstract}

Key words: maize, genotype, early maturity, plant spacing

\section{PENDAHULUAN}

Kebutuhan akan jagung terus meningkat sejalan dengan semakin berkembangnya usaha peternakan dan industri-industri yang membutuhkan bahan baku jagung. Peningkatan kebutuhan akan jagung ini diikuti dengan peningkatan produksi dan luas panen jagung dari tahun ke tahun. Namun produktifitas jagung per satuan areal masih sangat rendah. Hal ini dapat dilihat dari rata-rata produksi yang baru mencapai 4,74 ton/ha (BPS, 2014), sementara potensi produksi jagung dapat mencapai 8-12 ton/ha (Syuryawati,
Zubachtirodin, dan Rapar, 2000;

Subaedah et al., 2015).

Peningkatan produksi dapat dilakukan dengan jalan intensifikasi maupun ekstensifikasi. Usaha ekstensifikasi diperhadapkan pada pemanfaatan lahan kering iklim kering yang diperhadapkan pada ketersedian air yang terbatas (Subaedah et al., 2016) dan musim hujan yang pendek, sehingga diperlukan varietas yang sesuai, seperti misalnya varietas berumur genjah.

Pengembangan jagung umur genjah dan produksi tinggi, sangat penting artinya bagi petani dalam 
menghadapai perubahan iklim global. Menurut Sutaryo dan Samaullah (2001), umur panen merupakan karakter penting untuk bisa diterima petani. Namun demikian disamping umur panen yang singkat, juga sangat dipentingkan adalah tingkat produksi tanaman, karena tujuan akhir budidaya tanaman adalah pencapaan produksi yang maksimal.

Pengembangan varietas unggul jagung umur genjah (80-90 hari) dan super genjah (70-80 hari) merupakan salah satu upaya untuk meminimalisasi kegagalan panen akibat pendeknya periode hujan yang merupakan dampak dari perubahan iklim. Jagung umur genjah dan super genjah dapat diintegrasikan ke dalam sistem Pengelolaan Tanaman Terpadu (PTT) untuk meningkatkan Indeks Pertanaman (Anonim, 2011).

Produksi jagung berumur genjah lebih rendah daripada jagung berumur dalam, tetapi jagung berumur genjah toleran terhadap populasi yang tinggi, sehingga dapat ditanam dengan jarak tanam yang lebih sempit untuk meningkatkan produksi per satuan areal. Kepadatan populasi yang besar memungkinkan meningkatnya hasil biji per satuan luas. Oleh karena itu diperlukan pengaturan kerapatan tanaman yang optimal.

Banyaknya populasi tanaman per satuan areal ditentukan oleh jarak tanam yang digunakan. Peningkatan produksi tanaman jagung dapat dilakukan dengan mengatur kerapatan tanaman. Peningkatan kerapatan tanaman sampai batas tertentu dapat meningkatkan hasil biji. Penggunaan jarak tanam yang terlalu rapat akan menyebabkan antara daun sesama tanaman saling menutupi akibatnya pertumbuhan tanaman akan tinggi memanjang karena bersaing dalam mendapatkan cahaya sehingga akan menghambat proses fotosentesis dan produksi tanaman tidak optimal (Haryadi, 1997).

Berdasarkan uraian tersebut, maka dilakukan penelitian untuk menganalisis respon berbagai genotipe jagung pada berbagai jarak tanam.

\section{METODE PENELITIAN}

Penelitian ini dilaksanakan dalam bentuk percobaan di lahan kering Kabupaten Gowa pada bulan Mei sampai Juli 2017.

Bahan yang digunakan antara lain: benih jagung dari berbagai genotipe umur 
genjah yaitu G1, G2, G3 dan G4, pupuk yang disesuaikan dengan ketentuan kandang, label, pupuk NPK, urea, SP-36 perlakuan.

dan $\mathrm{KCl}$. Alat yang digunakan meliputi

Pemupukan diberikan 7 hari setelah timbangan, oven, meter, mistar geser, dan tanam dan pada saat tanaman berumur 30 lain-lain.

Penelitian dirancang mengikuti pola hari sesuai dengan dosis anjuran. Penyiangan dilakukan 2 kali dengan rancangan split-plot design. Sebagai membersihkan gulma yang berada di petak utama adalah genotipe jagung yang sekitar tanaman. Penyiangan pertama terdiri dari empat genotipe G1, G2, G3 dan G4. Sebagai anak petak adalah pengaturan jarak tanam yang terdiri dari tiga taraf yaitu : jarak tanam $70 \mathrm{~cm}$ x 20 $\mathrm{cm}(\mathrm{J} 1)$, jarak tanam $60 \mathrm{~cm} \times 20 \mathrm{~cm}(\mathrm{~J} 2)$ dan jarak tanam $50 \mathrm{~cm}$ x $20 \mathrm{~cm}$ (J3). Setiap kombinasi perlakuan diulang tiga kali sebagai kelompok sehingga diperoleh 36 satuan percobaan.

Persiapan lahan dimulai dengan pengolahan tanah yang dilakukan dengan pada waktu tanaman berumur 3 minggu setelah tanam (mst) dan 6 mst. Penyiangan kedua dapat dilakukan bersamaan dengan pembumbunan. Pembumbunan dilakukan untuk memperkokoh tanaman dan mempermudah pengairan pada petakan percobaan. Pelaksanaan panen dilakukan pada saat tanaman memasuki fase masak fisiologis dengan ditandai terbentuknya black layer pada biji. Adapun peubah cara pembajakan tanah kemudian yang diamati dalam penelitian ini: tinggi dilakukan penggaruan untuk tanaman, luas daun, komponen produksi menghancurkan bongkahan tanah dan dilakukan perataan serta rotari untuk lebih memperhalus tekstur tanah, kemudian tanaman jagung yang meliputi bobot tongkol, bobot 1000 biji serta bobot biji kering per ha hasil konversi.

lahan dibagi dalam 3 blok sebagai kelompok. Setiap blok di bagi menjadi empat petak utama yang berukuran $6 \mathrm{~m} \mathrm{x}$ $3 \mathrm{~m}$ selanjutnya petak utama dibagi menjadi 3 anak petak yang berukuran $3 \mathrm{~m}$ x $2 \mathrm{~m}$. Penanaman dilaksanakan dengan menggunakan tugal dengan jarak tanam 


\section{HASIL DAN PEMBAHASAN}

\section{Tinggi Tanaman}

Hasil analisis data tinggi tanaman jagungpada umur 8 MST menunjukkan bahwa terdapat interaksi yang nyata antara genotiper dan jarak tanam. Dari hasil uji lanjutan BNT yang disajikan pada Tabel 1 menunjukkan bahwa genotipe G3 dan G4 dengan jarak tanam yang lebih rapat $(60 \mathrm{x}$ $20 \mathrm{~cm}$ dan $50 \times 20 \mathrm{~cm}$ ) menghasilkan tanaman yang nyata lebih tinggi yaitu antara $293,47 \mathrm{~cm} \quad-295,07 \mathrm{~cm}$ dibandingan dengan jarak tanam $70 \times 20$ $\mathrm{cm}$.

Tabel 1. Tinggi tanaman jagung $(\mathrm{cm})$ dari bergagai genotipe umur genjah pada berbagai jarak tanam

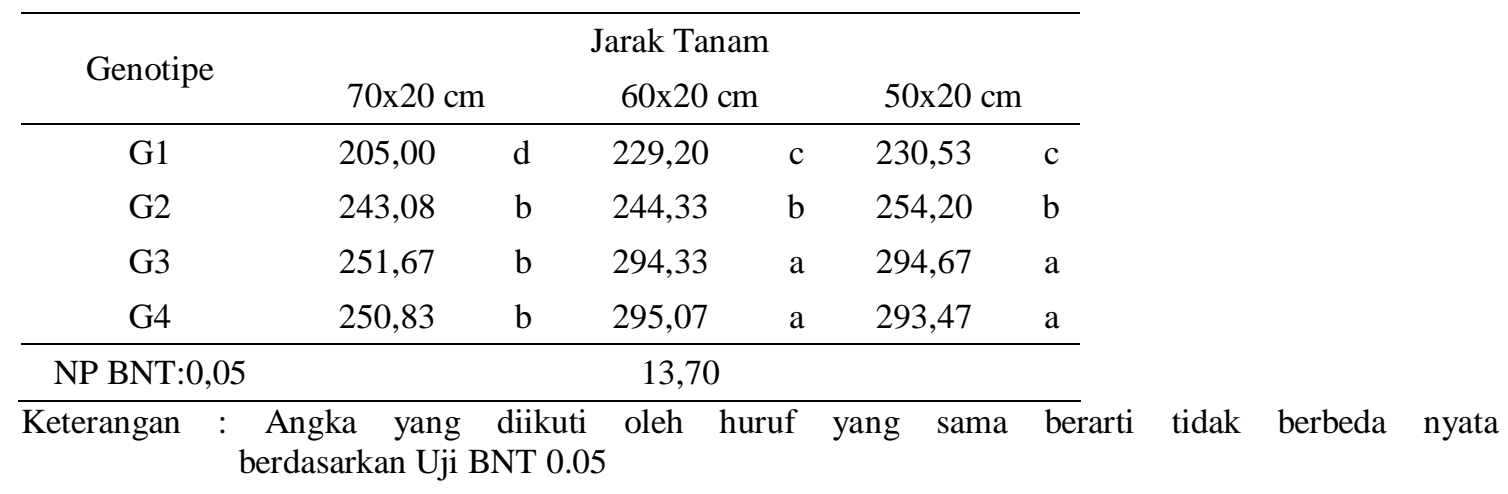

\section{Jumlah Daun}

Pengamatan terhadap jumlah daun menunjukkan bahwa perlakuan jarak tanam berpengaruh nyata terhadap jumlah daun yang dihasilkan tanaman jagung. daun yang lebih banyak yaitu 15,16 helai Hasil uji lanjutan BNT pada Tabel 2 dan berbeda nyata dengan genotipe G1 menunjukkan bahwa jarak tanam yang dan G3.

lebih rapat $(60 \times 20 \mathrm{~cm}$ dan $50 \times 20 \mathrm{~cm})$ diperoleh daun yang lebih banyak dibandingkan jarak tanam 70 x $20 \mathrm{~cm}$. Pada perlakuan genotipe menunjukkan bahwa genotipe G2 dan G4 diperoleh 
Tabel 2. Jumlah daun tanaman jagung pada umur 8 MST dari berbagai genotipe umur genjah pada berbagai jarak tanam

\begin{tabular}{ccccccc}
\hline \multirow{2}{*}{ Genotipe } & \multicolumn{3}{c}{ Jarak Tanam } & Rata-rata & NP BNT \\
& $70 \times 20 \mathrm{~cm}$ & $60 \times 20 \mathrm{~cm}$ & $50 \times 20 \mathrm{~cm}$ & & 0,05 \\
\hline G1 & 13,60 & 14,67 & 15,00 & 14,42 & $\mathrm{~b}$ & 0,58 \\
G2 & 15,00 & 15,40 & 15,07 & 15,16 & $\mathrm{a}$ & \\
G3 & 14,40 & 14,87 & 15,07 & 14,78 & $\mathrm{ab}$ & \\
G4 & 14,13 & 15,53 & 15,80 & 15,16 & $\mathrm{a}$ & \\
\hline
\end{tabular}

\begin{tabular}{lcccccc}
\hline \multicolumn{2}{c}{ Rata-rata } & $14,28 \mathrm{~b}$ & $15,12 \mathrm{a}$ & $15,23 \mathrm{a}$ & \\
\hline NP BNT: 0,05 & \multicolumn{2}{c}{0,29} & \\
\hline Keterangan $: \begin{array}{c}\text { Angka } \\
\text { berdasarkan Uji BNT 0.05 }\end{array}$ & diikuti oleh huruf yang & sama & berarti tidak berbeda nyata
\end{tabular}

\section{Panjang Tongkol}

Hasil analisis data panjang tongkol menunjukkan bahwa perlakuan jarak tanam berpengaruh nyata. Pada Tabel 3 menunjukkan bahwa rata-rata panjang dan $50 \times 20 \mathrm{~cm}$.

tongkol terpanjang diperoleh pada jarak tanam $60 \times 20 \mathrm{~cm}$ dengan panjang tongkol yang dihasilkan $17,55 \mathrm{~cm}$ dan berbeda nyata dengan panjang tongkol yang diperoleh pada jarak tanam $70 \times 20 \mathrm{~cm}$

Tabel 3. Rata-rata panjang tongkol jagung $(\mathrm{cm})$ dari berbagai genotipe umur genjah dan berbagai jarak tanam

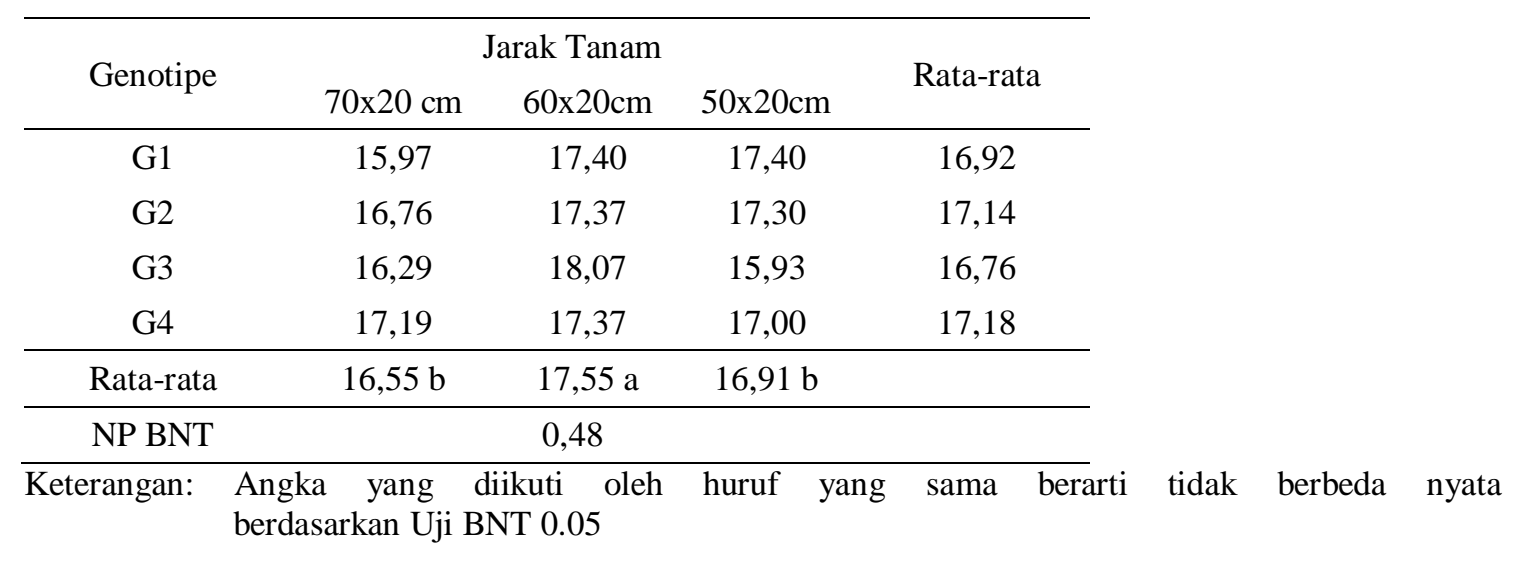




\section{Diameter Tongkol}

Rata-rata diameter tongkol yang disajikan pada Tabel 4 menunjukkan bahwa diameter tongkol terberat diperoleh pada genotipe $\mathrm{G} 2$ dan G4 dengan diameter tongkol yang dihasilkan masing-masing $4,50 \mathrm{~cm}$ dan $4,43 \mathrm{~cm}$ dan berbeda nyata dengan bobot tongkol yang diperoleh pada genotipe G1 dan G3.

Tabel 4. Diameter tongkol tanaman jagung $(\mathrm{cm})$ dari berbagai genotipe umur genjag dan berbagai jarak tanam

\begin{tabular}{|c|c|c|c|c|c|c|}
\hline \multirow{2}{*}{ Genotipe } & \multicolumn{3}{|c|}{ Jarak Tanam } & \multirow{2}{*}{\multicolumn{2}{|c|}{ Rata-rata }} & \multirow{2}{*}{$\begin{array}{c}\text { NP BNT } \\
0,05\end{array}$} \\
\hline & $70 \times 20 \mathrm{~cm}$ & $60 \times 20 \mathrm{~cm}$ & $50 \times 20 \mathrm{~cm}$ & & & \\
\hline G1 & 4,15 & 4,41 & 4,28 & 4,28 & $\mathrm{~b}$ & 0,15 \\
\hline $\mathrm{G} 2$ & 4,53 & 4,51 & 4,47 & 4,50 & $\mathrm{a}$ & \\
\hline G3 & 4,05 & 4,37 & 4,18 & 4,20 & $\mathrm{~b}$ & \\
\hline G4 & 4,33 & 4,45 & 4,49 & 4,43 & $\mathrm{a}$ & \\
\hline Rata-rata & 4,27 & 4,44 & 4,36 & & & \\
\hline
\end{tabular}

Keterangan : Angka yang diikuti oleh huruf yang sama berarti tidak berbedanyata berdasarkan Uji BNT0.05

\section{Bobot 1000 Biji}

Hasil analisis bobot 1000 biji kering menunjukkan bahwa perlakuan varietas dan jarak tanam berpengaruh nyata. Pada Tabel 5 diperlihatkan bahwa rata-rata bobot 1000 biji dari genotipe G3 dan G4 diperoleh bobot 1000 biji yang nyata lebih berat dari genotipe G2. Pada perlakuan jarak tanam menunjukkan bahwa jarak tanam $60 \times 20 \mathrm{~cm}$ diperoleh bobot 1000 biji yang nyata lebih berat dibandingkan dengan jarak tanam $70 \times 20 \mathrm{~cm}$ dan 50 x $20 \mathrm{~cm}$. 
Tabel 5. Rata-rata bobot 1000 biji jagung (g) dari berbagai genotipe dan berbagai jarak tanam

\begin{tabular}{|c|c|c|c|c|c|}
\hline \multirow{3}{*}{$\begin{array}{c}\text { Genotipe } \\
\text { G1 }\end{array}$} & \multicolumn{3}{|c|}{ Jarak Tanam } & \multirow{2}{*}{ Rata-rata } & \multirow{3}{*}{$\begin{array}{c}\text { NP BNT } \\
0,05 \\
20,44\end{array}$} \\
\hline & $70 \times 20 \mathrm{~cm}$ & $60 \times 20 \mathrm{~cm}$ & $50 \times 20 \mathrm{~cm}$ & & \\
\hline & 281,00 & 309,93 & 297,90 & 296,28 & \\
\hline G2 & 273,00 & 284,47 & 278,43 & 278,63 & \\
\hline G3 & 275,33 & 336,67 & 293,70 & 301,90 & \\
\hline G4 & 275,67 & 338,73 & 307,37 & 307,26 & \\
\hline Rata-rata & $276,25 \mathrm{c}$ & $317,45 \mathrm{a}$ & $294,35 \mathrm{~b}$ & & \\
\hline NP BNT 0,05 & & & 43 & & \\
\hline
\end{tabular}

\section{Produksi Biji Kering per ha}

Hasil analisis produksi biji kering per ha menunjukkan bahwa perlakuan varietas dan jarak tanam berpengaruh nyata. Rata-rata produksi biji kering per ha pada Tabel 6 menunjukkan bahwa perlakuan jarak tanam $60 \times 20 \mathrm{~cm}$ dan 50 x $20 \mathrm{~cm}$ diperoleh produksi biji kering yang nyata lebih tinggi yaitu $8,95-9,35$ t/ha dibandingkan produksi biji kering yang diperoleh dengan jarak tanam $70 \mathrm{x}$ $20 \mathrm{~cm}$. Pada perlakuan varietas terlihat bahwa genotipe $\mathrm{G} 4$ diperoleh produksi yang nyata lebih tinggi yaitu 10,25 t/ha dibandingkan genotipe lainnya.

Tabel 6. Produksi biji kering tanaman jagung (t/ha) dari berbagai genotipe umur genjah pada berbagai jarak tanam

\begin{tabular}{cccccccc}
\hline \multirow{2}{*}{ Genotipe } & \multicolumn{3}{c}{ Jarak Tanam } & & \multicolumn{2}{c}{$\begin{array}{c}\text { NP BNT } \\
0,05\end{array}$} \\
\cline { 2 - 4 } & $70 \times 20 \mathrm{~cm}$ & $60 \times 20 \mathrm{~cm}$ & $50 \times 20 \mathrm{~cm}$ & & & \\
\hline G1 & 6,99 & 8,57 & 9,01 & 8,19 & $\mathrm{~b}$ & 1,45 \\
G2 & 7,87 & 8,05 & 9,26 & 8,39 & $\mathrm{~b}$ & \\
G3 & 7,41 & 8,50 & 10,58 & 8,83 & $\mathrm{~b}$ & \\
G4 & 8,32 & 11,46 & 10,97 & 10,25 & $\mathrm{a}$ & \\
\hline Rata-rata & $7,64 \mathrm{~b}$ & $8,95 \mathrm{a}$ & $9,35 \mathrm{a}$ & & & \\
\hline NP BNT 0,05 & \multicolumn{7}{c}{0,74} \\
\hline
\end{tabular}

Keterangan : Angka yang diikuti oleh huruf yang sama pada baris dan kolom yang sama berarti tidak berbeda nyata berdasarkan Uji BNT 0.05 . 
Perbedaan jarak tanam genotipe yang diuji. Tingginya produksi memperlihatkan perbedaan pertumbuhan dari genotipe G4 juga ditunjang oleh tanaman. Hal ini dapat dilihat dari diameter tongkol yang lebih besar (Tabel variabel jumlah daun pada Tabel 2 yang 4) serta bobot 1000 biji yang lebih berat menunjukkan bahwa jarak tanam $50 \times 20$ (Tabel 5). Dengan diameter tongkol yang $\mathrm{cm}$ dan $60 \times 20 \mathrm{~cm}$ diperoleh daun yang lebih besar, memungkinkan jumlah baris lebih banyak dibandingkan jarak tanam 70 x $20 \mathrm{~cm}$. Hasil yang diperoleh ini sesuai dengan temuan Effendi (2006) yang mengemukkan bahwa jarak tanam lebih rapat menghasilkan jumlah daun yang lebih banyak dibandingkan jarak tanam yang lebih lebar. Dengan adanya daun yang lebih banyak akan memungkinkan penangkapan energi matahari yang lebih besar yang akan mengakibatkan proses fotosintesis berjalan lebih pesat dan pada akhirnya diperoleh produksi yang lebih besar dan ini dapat dilihat dari parameter panjang tongkol yang lebih panjang, bobot 1000 biji yang lebih berat, demikian pula produksi per ha lebih banyak pada perlakuan jarak tanam $60 \times 20 \mathrm{~cm}$ dan jarak tanam $50 \times 20 \mathrm{~cm}$.

Pada perlakuan genotipe biji lebih banyak dan dengan bobot biji yang berat memungkinkan produksi yang dihasilkan per satuan luas lebih berat pula. Buah jagung terdiri atas tongkol dan biji. Biji-biji jagung tersusun dalam barisan yang melekat secara lurus atau berkelokkelok pada tongkol jagung, sehingga dengan diameter tongkol yang lebar akan memungkinkan ruang peletakan biji lebih luas pula yang pada akhirnya akan menghasilkan tongkol yang bobotnya lebih berat, demikian pula dengan bobot 1000 butir yang lebih berat akan menghasilkan bobot pipilan jagung yang diperoleh akan lebih berat pula. Pada perlakuan jarak tanam menunjukkan bahwa jarak tanam yang lebih rapat $(60 \mathrm{x}$ $20 \mathrm{~cm}$ dan $50 \times 20 \mathrm{~cm}$ ) diperoleh produksi yang nyata lebih tinggi yaitu 8,95-9,35 menunjukkan bahwa genotipe G4 t/ha dibandingkan dengan jarak tanam 70 diperoleh produksi yang nyata lebih tinggi dibandingkan dengan genotipe lainnya. Perbedaan produksi dari genotipe yang diuji berhubungan dengan potensi genetik dari masing-masng x $20 \mathrm{~cm}$ yang hanya menghasilkan produksi sebesar 7,64 t/ha. Hal ini disebabkan pada jarak tanam yang lebih rapat diperoleh populasi yang lebih banyak dibandingkan dengan jarak tanam 
yang lebih lebar. Hal ini sesuai dengan yang dikemukakan oleh Berger (1962), jumlah tanaman per satuan luas sangat mempengaruhi produksi jagung. Pengaruh bertambahnya populasi per hektar menurut Sudjana et al. (1991) akan diikuti oleh peningkatan hasil tanaman jagung.

Interaksi antara genotipe dan jarak tanam berpengaruh nyata pada parameter tinggi tanaman. Hal ini sesuai dengan apa yang diperoleh Marliah, Hidayat dan Husna (2012) yang menyimpulkan bahwa terdapat interaksi yang nyata antara varietas dan jarak tanam terhadap pertumbuhan dan produksi tanaman. Pada Tabel 1 dapat dilihat bahwa genotipe G3 dan G4 menghasilkan tanaman yang lebih tinggi dengan jarak tanam yang lebih rapat $(60 \quad \mathrm{x} \quad 20 \mathrm{~cm}$ dan $50 \quad \mathrm{x} \quad 20 \mathrm{~cm})$ dibandingkan dengan jarak tanam yang lebih lebar $(70 \times 20 \mathrm{~cm})$.

\section{KESIMPULAN}

Pertumbuhan dan produksi tanaman jagung dipengaruhi oleh genotipe dan jaram tanam yang digunakan. Genotipe jagung G3 dan G4 menghasilkan tanaman yang lebih tinggi dengan jarak tanam yang lebih rapat $(60 \mathrm{x}$ $20 \mathrm{~cm}$ dan $50 \times 20 \mathrm{~cm}$ ) dibandingkan dengan jarak tanam yang lebih lebar $(70 \mathrm{x}$ $20 \mathrm{~cm}$ ). Pada perlakuan jarak tanam menunjukkan bahwa jarak tanam $60 \times 20$ $\mathrm{cm}$ dan 50 x 20 diperoleh produksi yang nyata lebih tinggi yaitu antara 8,95 - 9,35 t/ha dibandingkan dengan jarak tanam 70 x $20 \mathrm{~cm}$ yang hanya menghasilkan produksi 7,64 t/ha

\section{DAFTAR PUSTAKA}

Anonim. 2011. Jagung Hibrida Unggul Nasional. Agroinovasi, Sinar Tani, Edisi 26 Januari-1Pebruari 2011.

Berger, J. 1962. Maize Production and Manuring of Maize. Centre d'Etude de l'Azote, Geneva. 315 pp.

Biro Pusat Statistika. 2014. Statistik Indonesia. http://www.bps.go.id

Efendi. 2010. Pertumbuhan dan produksi kedelai melalui kombinasi pupuk organik Lamtorogung dengan pupuk kandang. Jurnal Floratek 5:65-73.

Effendi, Fetrie Bestiarini. 2006. Uji beberapa varietas jagung (Zea mays L.) pada tingkat populasi tanaman yang berbeda. Fakultas Pertanian, IPB Bogor.

Haryadi, Sri Setyati. 1997. Pengantar Agronomi. PT. Gramedia, Jakarta.

Marliah, A., T. Hidayat dan N. Husna. 2012. Pengaruh jarak tanam dan varietas terhadap pertumbuhan 
kedelai (Gycine $\max$ L. Merrill). Sutaryo, B dan M. Y. Samaullah. 2000. Jurnal Agrista 16(2):22-28. Keragaman Hibrida-Hibrida Padi Turunan Enam Galur Mandul Jantan

Subaedah, St., A.Aladin dan Nirwana. 2015. Fertilization of Nitrogen, Phosphor and Application of Green Manure of Crotalaria juncea In Increasing Yield of Maize In Marginal Dry Land. Agriculture and Agricultural Science Procedia 9:20-25.

Baru. J. Agrotropika 5 (2) : 1-5.

Syuryawati, Zubachtirodin, C. Rapar. 2000. Deskripsi Varietas Unggul Jagung. Badan Penelitian dan Pengembangan Pertanian. Balai Penelitian Tanaman Jagung dan Serealia Lain. Maros. 66p.

Subaedah, St., A.Takdir, Netty, Hidrawati. 2016. Evaluation of Potential Production of Maize Genotypes of Early Maturity in Rainfed Lowland. International Jornal of Biological, Biomolecular, Agricultural, Food and Biotechnological Engineering. 10(10):584-587.

Sudjana, A., A. Rifin, dan M. Sudjadi. 1991. Jagung. Bul. Teknik No.4 . Balai Penelitian Tanaman Pangan. Bogor. 42 hal. 